\title{
Incorporating information literacy in the Croatian school environment
}

\author{
Mihaela Banek Zorica ${ }^{1}$, Sonja Spiranec ${ }^{2}$ \\ University of Zagreb, Faculty of Humanities and Social Sciences, Department of Information \\ Sciences, I.Lucica 3, 10000 Zagreb, Croatia \\ mbanek@ffzg.hr$r^{1}$ sspiran@ffzg.hr ${ }^{2}$
}

\begin{abstract}
Despite the relevance, potential and impact of IL activities on the wider social and pedagogical context, libraries in Croatia are lagging far behind the emerging global information literacy movement. Due to the general lack of written and widely published educational programs, mission statements or policies of Information Literacy on a national level, the majority of school libraries in Croatia are forced to provide only simple and most fundamental forms oriented more towards library and not information literacy. Diagnosing the emerging problem and trying to find a solution to the problem presented an idea for a pilot project. Educating the educators i.e. school librarians was set as a starting point in implementing information literacy in the educational environment.
\end{abstract}

Results of the pilot project carried out with the Education and Teacher Training Agency in advocating information literacy in the school environment are presented in this paper. Research on the theory of current education problems together with research on best case scenarios was used as a foundation for creating learning materials and organizing a series of workshops for educating school librarians. Future plans for expanding the project with all participants of the educational process (principals, teachers and school librarians) are discussed and key elements of possible information literacy program are defined.

\section{Introduction}

Changes in the educational environment have influenced how we define information literacy and information literate persons. Still, in the broadest context and as a starting point we can use the ALA (1989) definition of a information literate person as the one who has "learned how to learn". As discussed later in the text it presents a starting point incorporated in the new educational curriculum as one of the major outcomes of the learning process. The complementarities of information literacy with contemporary educational reforms are metaphorically described by many authors who refer to information literacy as a precondition for survival and success in an information/technology environment and for leading a productive, healthy and satisfying live in a democratic society (Bawden, 2001). Information literacy is defined as a "catalyst for educational change" (Bruce, 2002, p.1), a revolution in education (Breivik, 1999, p. 271), the key to lifelong learning (Špiranec, 2003) or as an enabler for bridging digital divides and for participation in the democratic environment (Prague Declaration, 2003).

The correlation between information literacy and new models of learning is a strong one and derives from the contemporary complex and dynamically changing information universe where content is unfiltered and unorganized and the information flood is uncontrolled and overwhelming. Since the basic component of education is information, the new pedagogical paradigms are based on the premise of constant interactions with the present complex information environment, where the learner constructs knowledge rather than passively receives it. Information literacy presents a form of empowerment for the learner, who does not depend solely on the teacher when acquiring knowledge. $\mathrm{He}$ is involved in the discovery of knowledge and learns from interactions with available resources. Information literacy prepares learners to connect, interact and utilize this accessible wealth of information (Todd, 2001), not just in periods of compulsory schooling and under the supervision of a teacher as an authoritative knowledge resource but independently throughout their lives by strategically gathering, evaluating, synthesizing and presenting information. (Lasić-Lazić, Špiranec, Banek Zorica, 2006.) 


\section{School libraries in Croatia}

In the Croatian school system it is prescribed by the law that every school is obliged to have a school library. The Law on Primary and Secondary Education (2003), stipulates that every school must have a school library emphasizing its role by defining it is as a"... part of the educational process in which professional library activities are conducted on a smaller scale usually serving the realization of the educational process ... it must be governed by rules laid down by the standards for school libraries." The Standard (Standard za školske knjižnice, 2000) prescribes the conditions that each library must meet regarding the space, collections and set of goals by utilizing three major activities: educational, cultural/public and professional. Furthermore, the State Educational Standard (Državni pedagoški standard, 2008) stands as another document which defines the school library as a social space which is "... an integral part of the educational system, directly involved in teaching and extracurricular activities" specially emphasizing its need to "... adapt to changes in the school education program and the emergence of new technologies". As will be discussed later in the section on educational reforms, these legal documents and regulations provide a clear picture of what the school library is and should be. Unfortunately documents regarding the curricular reform often lack the vivid integration of the school library and its role in the curriculum. This situation leaves school librarians constantly struggling for recognition as equal partners with dedicated time and space in the achievement of students learning outcomes and educational goals.

It is necessary to state that school librarians in Croatia are among the most educated ones in the school environment. Apart from having a university degree from any discipline they also need to acquire a degree in school librarianship. Obtaining a degree in librarianship is possible at any of three universities: Zagreb, Osijek and Zadar. In order to be able to work in the library one can either get employed with already acquired library degree during their full time studies or can enrol in part- time study after being appointed to the position of school librarian. This is regulated by the document on qualification of staff employed in the primary and secondary school (Pravilnik o stručnoj spremi i pedagoško-psihološkom obrazovanju učitelja i stručnih suradnika u osnovnom školstvu, 1996) which stipulates who can be appointed to the position of school librarian and which conditions they have to meet:

- a professor of Croatian language and literature or Comparative literature, provided that within 2 years the person obtains a library degree

- a professor, with more than 5 years of teaching experience, provided that within 4 years the person obtains a library degree

- a professor, with more than 10 years of teaching experience, provided that within 2 years the person obtains a library degree

- a teacher of any subject, according to a special approval of the Ministry of Education and Sports

Still, continuous education of all teaching and professional staff is required and enabled through the Education and Teacher Training Agency. ${ }^{1}$ This public institution is responsible for the provision of professional and advisory support in the area of general education in Croatia. It is an Agency of the Ministry responsible for educational issues. The main scope of the Agency lies in providing professional and advisory assistance in education, monitoring and improvement of education, the participation in the preparation of the national curriculum, organising and implementing in-service training of pre-school, primary and secondary-school teachers, school counsellors and principals etc.

The Agency provides a systematic continuous professional training of school librarians on two levels:

- County level - the organization of training in counties organized by the school librarian elected as the head of the county council.

- State level - together with the Department of Information Sciences, Faculty of Humanities and Social Sciences, University of Zagreb it organizes a Spring School of Croatian school librarians. The first one was organized in 1988 and it presented an organized form of professional

\footnotetext{
${ }^{1}$ http://www.azoo.hr/index.php?option=com_content\&view=article\&id=1999\&Itemid=343
} 
development based on the both theoretical and practical level. Secondly, the Agency regularly organizes gathering and continuous education, workshop and seminar based, for the head council librarians

In addition, school libraries as part of the Croatian library network also have support from the National and University Library which has a dedicated school library adviser coordinating a network of public librarians from each county. The main task is to provide support for school librarians in each county.

\section{Educational changes in Croatian primary and secondary education}

The essence of developments directed towards building a modern information society is captured in a program launched and approved by the Croatian government entitled "Croatia in the $21^{\text {th }}$ century" (2003). The program was oriented towards producing different strategies in various fields (such as education, information technology, macro economy, science etc.) in order to respond to the requirement of the knowledge- based economy. The educational sector has oriented itself towards creating their strategy starting with the project oriented towards primary and secondary education ${ }^{2}$. The project was launched in the year 2005 as the Croatian National Educational Standard (Guide, 2005) which tired to articulate and recommend educational reforms setting the new educational objectives corresponding to the objectives that dominated in the educational sector in the EU. The Standard was generated as a result of the recognized problems of overloading pupils, inadequate teaching methods and insufficient monitoring and evaluation of the quality of education. In its essence, it acknowledges that it is important to relieve pupils from encyclopaedic content and direct them toward creativity, problem-solving abilities and lifelong learning. Although it aimed to cover both levels of educational, in the end, test bed institutions were only from primary schools thus resulting in formulation of the state wide curriculum only for primary school (Nastavni plan i program za osnovnu školu, 2006.).

The next logical step was to create a document that would cover all levels of school education, i.e. pre-school, primary and secondary level and give a complete and thorough overview of the goals of educational reforms on all levels. The new document aiming to cover all aforementioned levels was presented in 2007 as National Curriculum Framework - NCF (Nacionalni okvirni kurikulum, 2007). The NCF derives from the European document and guidelines such as The European Qualification Framework for Lifelong Learning (2008) presenting a framework for acquiring of "fundamental and professional competencies". The document serves as a foundation for development of subject curriculum on different educational levels. The main focus is now moved towards a set of competencies and learning outcomes in the effort to connect various core, faculty and elective courses in one unique curriculum. By utilizing a combination of subject courses and cross course topics together with set of competencies and learning outcomes it presents a new approach oriented towards students' educational goals and aims. The key competencies identified as the ultimate result of the educational process are:

1. communication in the mother tongue

2. communication in a foreign language

3. mathematical competence and basic competencies in science and technology

4. digital competence

5. learning how to learn

6. social and civic competence

7. initiative and entrepreneurial competence

8. cultural conciousness and expression.

The position of the school library is differently identified in these two documents. Although the first one still defines the school library and its activity as, "...oriented towards information literacy and

\footnotetext{
${ }^{2}$ In Croatia, primary school education consists of a total of 8 years. Upon the completion of 8 th grade, pupils advance to secondary school with the option of enrolling into either a four-year Grammar school (Gymnasium) or a three/four year vocational school.
} 
promotion of reading", the later one, i.e. NCF, positions the school librarian's role rather vaguely. The school library is not mentioned as such but can rather be recognized in the set of competencies and more precisely in the description of the competence of "learning how to learn", and as a support to development of the other seven competencies. The problem school librarians are facing due to this situation is their unclear position in the curriculum which leads to their not being recognized by the other members of school community. Thus, school librarians are left to struggle for recognition and in adjusting their activities and mission in the new educational reform.

\section{Project of information literacy advocacy among school librarians}

Educational reforms implemented in Croatia have brought new tasks on school librarians making them a key factor not only in the educational process but also in the information environment. Due to the general lack of written and widely published educational programs, mission statements or policies of Information literacy on national level, the majority of school libraries in Croatia are forced to provide only simplest and most fundamental forms oriented more towards library and not information literacy. Still, for educational reforms to be applied in everyday practice, it is important to recognize that the learning environment is larger than the school, that learning happens on the global information infrastructure and through interaction with information and that information literacy attributes like accessing, evaluating, and using information are integral to understanding content and crucial for learning success.

Analysis of the current state of school libraries and their information literacy programs identified some major obstacles to creating a successful information literacy friendly environment. This came to our attention from previous research done at the Department of Information Sciences, Faculty of Humanities and Social Sciences, University of Zagreb. Obstacles which seem most relevant to information literacy are: lack of teacher and principal support; lack of collaboration between school librarians and teaching staff; principal and teachers not seeing school librarians as part of educational process; lack of understanding of the concept of information literacy both among teachers and some school librarians; lack of library staff and space (Špiranec, Banek Zorica, 2008). Problems that have emerged as the most important ones and which needed immediate action were the ones regarding the lack of written and widely published educational programs, mission statement or policy of Information Literacy on a national level. Therefore, the majority of school libraries in Croatia are forced to provide only simplest and most fundamental forms of user education oriented more towards library and not information literacy. Diagnosing the problem and trying to find a solution resulted in the development of the idea for the pilot project.

The purpose of the pilot project was to promote IL among school library practitioners in Croatia but also making the wider school community to think about IL and perceive it as a tool for the realization of current educational reforms. In order to do this the target audience of the workshop could not be restricted to school librarians but the wider IL/school community. Education of practitioners was seen as model of training the trainers and additional value for their recognition as the crucial factors of educational process in the eyes of the whole school community. In order to reach the wider community, the workshop facilitators approached the Education and Teacher Training Agency which agreed to participate in the project. The alliance with this institution gave the project an important strategic dimension. The Education and Teacher Training Agency is a public institution responsible for the provision of professional and advisory support in the area of general education in Croatia; it is an Agency of the Ministry of Education. Its main scope lies in providing professional and advisory assistance in education, monitoring and improvement of education, the participation in the preparation of the national curriculum, organizing and implementing in-service training of pre-school, primary and secondary-school teachers, school counsellors, principals etc. The support of such an institution guaranteed that the workshops will have a strong voice and echo in the wider school community. (Špiranec, Banek Zorica, 2011.) 


\section{Methodology}

Research on theoretical frameworks and scanning of current education problems and IL issues together with research on best case scenarios served as a good foundation for creation and organisation of the set of materials to be offered on beginners and advanced level. From the practical point of view knowledge acquired at the UNESCO-s Training-the-Trainers Workshop held in Ankara in 2008 (Kurbanoglu, 2010) was utilized in the creation and adoption of resources and materials for information literacy workshops. Specific needs and issues arising in the context of the Croatian school community had to be taken into account while designing workshops for different sets of participants. The aims and objectives of the workshop were twofold. First, were educational outputs relating to information literacy awareness and know-how while second, and less obvious, is that of the formulation and articulation of priorities from the viewpoint of the professional and the articulation of a national IL strategy. The educational outcomes of the program were accomplished by a combination of presentations, demonstrations, hands-on activities and exercises. The second aim, namely to define national priorities of IL actions and activities, was accomplished through group work and discussions.

In 2010, eight workshops with a regional scope were organized with the prospect of organizing several more in 2011 covering the two Croatian regions not included in the first cycle of workshops. The target audience for the first six workshops were teacher-librarians while the additional two workshops tried to target a much wider audience trying to connect different members of the school community teachers, librarians, headmasters and representatives of the Ministry of Education responsible for teacher-training. The heterogeneity of this group of participants brought in different perspectives and viewpoints, which proved to be highly beneficial for the workshop outcomes. In total, 250 participants attended the workshops although some of the participants, namely school librarians, showed special interest and motivation in the subject and the workshops by attending more than one workshop, both beginners and advanced ones.

\section{Results and discussion}

Through self-reflecting analysis and group discussions about major obstacles in delivering information literacy at schools the participants highlighted a set of obstacles. After the initial discussion, workshop participants were asked to propose a set of solutions for the perceived problems and barriers in offering information literacy. During the two group activities transcripts of the discussions were made.

The different statements relating to major obstacles in making IL a school-wide issue were summarized into four main categories:

1. Educational policy issues - school librarians are facing obstacles such as lack of dedicated IL time in the planned curriculum, no recognition of IL within the curriculum and lack of national IL standard or curriculum

2. Financial and administrative support i.e. lack of resources

3. Institutional issues such as resistance to change and lack of commitment for information literacy across the school community

4. Competencies - confusion of information literacy with IT competency, among teachers and even among librarians, need for educating teachers

Analysis of responses indicated that the majority of participants perceived strategic issues as a major obstacle in implementing IL in schools. Without adequate frameworks librarians are not sure where to start with their IL activities, how to justify such activities or how to promote or advocate them. Those issues were identified as those needing immediate attention.

The next step was to define a set of actions to be taken to address the identified obstacles. Participants were given open hands in articulating their viewpoints of what is needed in order to overcome defined obstacles. During group discussions the participants identified the following issues:

- awareness-raising of teachers and principals

- education of teachers about IL concepts and outcomes

- integration of IL across the curriculum

- investments in infrastructure and resources 
- verification of a national IL program/curriculum

- developing IL standards

- develop and teach an IL curriculum that is integrated with core subject areas

- need for teachers to reinforce the IL skills thought by librarians

\section{Fostering solid understanding of IL across the school community}

The project developed a comprehensive workshop rationale with several considerations in mind. First and foremost was that information literacy is not just a library issue, but an issue of concern for the whole educational/school community and society as well. Therefore, the results of the workshop needed to be developed through a cooperative and collaborative process that included representatives from different stakeholders i.e. librarians, headmasters, IL researchers/LIS teachers, public librarians, representatives from teacher training agency. It is interesting to highlight that solutions elicited in the group work which involved aforementioned information literacy stakeholder were much wider in scope. Some of the suggested solutions arouse through the discussion in the mixed groups of participants coming from different positions in school. Ones that were identified as of top priority were:

- creation of IL taskforces on the school community level

- need for illustrating and highlighting correlations between IL and educational reforms (promoting IL as a vehicle of educational reforms)

- making more clear how to integrate IL into subject-specific content

- strengthening and institutionalising collaborative efforts, fostering cooperation with teachers,

- developing mechanisms for articulation within the curriculum, school mission and strategic plans

- institutionalizing the collaboration with public librarians, defining modes of this collaboration

- involvement of parents into IL discussions and actions

The discussions between different groups showed much more understanding of the problem and created a collaborative environment focused on the educational goal having the best interest of the student in mind. Although, similar types of activates still need to be done in order to prove that this is the more efficient way of communicating and helping all the participants of the educational process, still these two workshops have proven that there is a general lack of communication and understanding of the problem and not just utilizing theoretical knowledge published in the official state documents.

The workshop outcomes and things learned and discussed served as a foundation for defining a solid and sustainable IL framework based on real-life problems and situations from the perspective of professionals and through discussion of different school community members. Three main areas can be defined as workshop outcomes (Spiranec, Banek Zorica, 2011):

- Educational aims: After completing either beginners or advanced workshop (in some cases school librarians were attending both) participants have gathered insight into the field of information literacy and its implementation into the curriculum. Practical examples oriented towards standards, performance indicators, learning outcomes, the creation of a successful IL programs, evaluation of information and information literacy perception and communication were appropriately taken from the everyday practice and the body of knowledge accredited and implemented in schools. Participants were encouraged to further develop materials received either by themselves or by joining forces and sharing best examples. Needless to say that the two workshops that hosted the wider school community were to a large extent advocacy-related and oriented towards demonstrating the correlation between educational reforms and IL and the meaning of IL for learning success.

- Building up communities: Apart from workshops designed for school librarians the two workshops held for the community of both management and information personnel i.e. head masters, school librarians and public librarians brought some new perspectives into the workshop and gave the learning events additional value. This type of workshop brought closer 
connection between key elements of successful educational process. Communication between principals and school librarians and their insight in current obstacles and possible solution was seen as a good practice in fostering dialogue and helping transfer the idea and understanding of inclusion of the information literacy into everyday educational practice.

- Defining sustainable bottom-up strategies from practitioners' viewpoint: Major obstacles to IL in the context of school libraries were elicited during group discussion and possible solutions to obstacles proposed. After identifying main inhibiting IL factors, the participants proposed solutions on the spot. These agreed points were transformed into a realistic IL agenda for school libraries.

These outcomes and set future steps are oriented towards the whole school community and not only towards school library. This confirms the standpoint that the learning environment is larger than the school and spreads further in the information infrastructure. For a successful learning process, therefore, students need to adapt information literacy skills which help them access, evaluate and use information in order to understand content and develop critical thinking necessary for learning and functioning in today's knowledge society.

Therefore, we can state that the result of this project are oriented towards the development of a national IL standard based on a taskforce consisting of highly motivated and interested workshop participants who will work on the standard. Representatives from the Education and Teacher-Training Agency need to communicate this work to the Ministry of Education in order to accredit the standard. Still, continuous education of school librarians in information literacy through this type of workshop need to be performed regularly together with the creation of documents and books practically oriented containing best cases scenarios and instruction for successful implementation of information literacy in learning process.

\section{Conclusion}

Practice has shown that there is still a lot of misunderstanding of the term information literacy being mixed with computer literacy and library skills. Progressive advocacy of information literacy shows results in recognition of the problem and comprehending this kind of literacy as one of the solutions to the successful educational reform. Insight into the school librarian's position and view of the problem as well as their suggestions of how to create possible solutions to the problem, both on general and individual level is seen as an excellent foundation for creating national strategies, standards or programs. The main premise of the set of workshops was that the process of devising strategies or programs shouldn't be completely left to decision-makers that don't have insight to priorities, real-life problems and issues that school librarians face in their every-day practice. Furthermore, viewpoints of different potential stakeholders and the wider school community should be incorporated into any IL strategy and, finally, the workshop organizers believed that "the iron should be beaten while it is hot", therefore coupling educational and motivational moments with observations and proposals of participants expressed right on the spot as the basis for further steps in creating IL agenda.

Instead of creating top-down strategies that may be detached from real-world professional situations, burdens and barriers or approaches restricted to viewpoints of decision-makers or just one segment of a wider community, it is important to provide a platform of different voices and angles, which was accomplished by the conception of the workshops held. The applied methodology proved to be fruitful, sustainable and comprehensive; it will therefore provide a model for future IL workshops based on following guidelines:

1. the linking of learning events with critical analysis and self-analysis of the current situation involves and motivates the learner

2. dealing with neuralgic points and proposing solutions tailored to the perceived problems of practitioners suggest future directions and form a usable basis for creating an IL agenda

3. embracing the wider community - not just librarians but other constituents of IL school community as well 
The educational-analytical-operational framework of the workshop proved to be useful for developing the knowledge of teacher-librarians and also others involved in supporting effective school libraries, i.e. headmasters and public librarians. By working through multi-perspective alliances in this way, librarians can have far more influence on high-level decision-making than they can as individuals and create solutions tailored to their immediate professional needs.

\section{Three key learnings:}

- After completing either beginners or advanced workshop (in some cases school librarians were attending both) participants have gathered insight into the field of information literacy and its implementation into the curriculum. Practical examples oriented towards standards, performance indicators, learning outcomes, the creation of a successful IL programs, evaluation of information and information literacy perception and communication were appropriately taken from the everyday practice and the body of knowledge accredited and implemented in schools. Participants were encouraged to further develop materials received either by themselves or by joining forces and sharing best examples. Needless to say that the two workshops that hosted the wider school community were to a large extent advocacy-related and oriented towards demonstrating the correlation between educational reforms and IL and the meaning of IL for learning success.

- Communication between principals and school librarians and their insight in current obstacles and possible solution was seen as a good practice in fostering dialogue and helping transfer the idea and understanding of inclusion of the information literacy into everyday educational practice.

- Sustainable bottom-up strategies from practitioners' viewpoint still need to be defined.

\section{References}

Bawden, D. (2001). Information and digital literacies: a review of concepts. Journal of documentation, 57(2), 218-59.

Breivik P.S. (1999). Take II - information literacy: revolution in education. Reference Services Review, 27(3), 271-276.

Bruce, C. (2002). Information literacy as a catalyst for educational change: a background paper. White Paper prepared for UNESCO, the U.S. National Commission on Libraries and Information Science, and the National Forum on Information Literacy, for use at the Information Literacy Meeting of Experts, Prague, The Czech Republic. Retrieved from: http://citeseerx.ist.psu.edu/viewdoc/download?doi=10.1.1.113.3967\&rep=rep1\&type=pdf

Lasić-Lazić, J. Špiranec, S. Banek Zorica, M. (2006). Information literacy: the backbone of curricular school reforms in Croatia. In A.B. Martus (Ed.), The multiple faces of literacy: reading, knowing, doing. Proceedings of the Annual IASL Conference ,Lisbon, Portugal.

Ministarstvo znanosti, obrazovanja i športa RH. (2008). Državni pedagoški standardi. Zagreb: MZOŠ

Guide through the Croatian National Educational Standards for Primary schools. (2005). Retrieved from http://www.mzos.hr/datoteke/hnos/cnes.pdf

Ministarstvo prosvjete i športa. (1996). Pravilnik o stručnoj spremi i pedagoško-psihološkom obrazovanju učitelja i stručnih suradnika u osnovnom školstvu. Zagreb: Narodne novine. Retrieved from: http://www.azoo.hr/images/stories/dokumenti/propisi/Pravilnici_09.pdf

Ministarstvo prosvjete i športa. (2000) Standard za školske knjižnice. Zagreb: Narodne novine Retrieved from http://narodne-novine.nn.hr/clanci/sluzbeni/272719.html

Nastavni plan i program za osnovnu školu. (2006.) Zagreb : Ministarstvo znanosti, obrazovanja i športa. Retrieved from: http://public.mzos.hr/fgs.axd?id=14181 
Strategija razvitka Republike Hrvatske "Hrvatska u 21. stoljeću" - znanost (2003). Zagreb: Narodne novine Retrieved from:; http://narodne-novine.nn.hr/clanci/sluzbeni/306017.html

Špiranec, S. (2003). Information literacy: key to lifelong learning <In Croatian>. Edupoint, 3, 17. Retrieved from: http://www.carnet.hr/casopis/17/clanci/1

Špiranec, S. Banek Zorica, M. (2008) Informacijska pismenost : teorijski okvir i polazišta. Zagreb : Zavod za informacijske studije Odsjeka za informacijske znanosti Filozofskog fakultetaSveučilišta u Zagrebu

Špiranec, S. Banek Zorica, M. (2011). Developing understanding of information literacy within the Croatian school environment. In L.Marquardt \& D. Oberg (Eds.), Global perspectives on school libraries: Projects and practices (pp. 33-43). Berlin/New York: De Gruyter Saur.

European Communities. (2008). The European Qualifications Framework for Lifelong Learning (EQF). Luxembourg: Office for Official Publications of the European Communities. Retrieved from http://ec.europa.eu/dgs/education_culture/publ/pdf/eqf/broch_en.pdf

The Prague Declaration. (2003). Towards an information literate society . Retrieved from: http://portal.unesco.org/ci/en/files/19636/11228863531PragueDeclaration.pdf/PragueDeclaration.pdf

Todd, R. (2001). Transitions for preferred futures of school libraries: knowledge space, not information place, connections, not collections, actions, not positions evidence, not advocacy. Paper presented at the 30th Annual conference of the International Association of School Librarianship, Auckland, New Zealand. Retrieved from http://www.iasl-online.org/events/conf/virtualpaper2001.html

Zakon o odgoju i obrazovanju u osnovnoj i srednjoj školi. (2008). Retrieved from: http://narodnenovine.nn.hr/clanci/sluzbeni/340388.html

\section{Biographical Note}

Mihaela Banek Zorica, Ph.D., is an Assistant professor at Department of Information Sciences, Faculty of Humanities and Social Sciences, University of Zagreb, where she teaches subjects related to knowledge organization, e-learning, school libraries, and information literacy. She has been working on several international and national projects. Her research interests are on e-learning, repositories, knowledge organization, school libraries and information literacy on which she has published several papers, book chapters and books. In 2010 she received IASL school librarianship award and University of Zagreb e-learning award for the course with the best utilization of social software in elearning.

Sonja Špiranec is an Assistant professor at the Department of Information Sciences, Faculty of Humanities and Social Sciences, University of Zagreb. She holds a PhD in Information Sciences \& librarianship from the University of Zagreb. She is engaged in undergraduate, graduate and postgraduate teaching, mentoring and research in the area of information retrieval, evaluation of information, information literacy, scientific communication and Web 2.0. In 2008 she has published a textbook on information literacy in Croatian. She has participated in numerous international conferences and workshops and received in 2010 the annual national award for using social software in education.

\section{Statement of originality}


This statement certifies that the paper above is based upon original research undertaken by the author and that the paper was conceived and written by the author(s) alone and has not been published elsewhere. All information and ideas from others is referenced. 